\title{
Celecoxib inhibits growth of tumors in a syngeneic rat liver metastases model for colorectal cancer
}

\author{
Pieter de Heer • Maro H. Sandel • Gunther Guertens • Gert de Boeck • \\ Margaretha M. Koudijs · J. Fred Nagelkerke · Jan M. C. Junggeburt • \\ Ernst A. de Bruijn · Cornelis J. H. van de Velde • Peter J. K. Kuppen
}

Received: 19 June 2007 / Accepted: 21 December 2007 / Published online: 5 February 2008

(C) The Author(s) 2008

\begin{abstract}
Introduction Nonsteroidal anti-inflammatory drugs (NSAIDs) have been shown to reduce the risk of colorectal cancer in cyclooxygenase-2 (COX-2) overexpressing colorectal cancers. The present study was designed to evaluate the inhibitory effects of the COX-2 inhibitor celecoxib on the growth of colorectal cancer liver metastases in a syngeneic rat model, CC531.

Materials and methods The effects of celecoxib on cell viability in vitro were evaluated by treatment of CC531 tumor cell cultures with celecoxib. In vivo, Wag/Rij rats were inoculated with CC531 tumor cells at two sites in the liver and treated with celecoxib starting one week before, or directly after tumor inoculation. Control rats were inoculated without treatment. Three weeks after tumor inoculation rats were sacrificed. Tumor size, immune cell infiltration, caspase-3 activity, $\mathrm{PGE}_{2}$ and celecoxib levels were determined.
\end{abstract}

P. de Heer · M. H. Sandel · M. M. Koudijs · J. M. C. Junggeburt .

C. J. H. van de Velde · P. J. K. Kuppen ( $\square)$

Department of Surgery, K6-R, Leiden University Medical Center,

P.O. Box 9600, 2300, RC Leiden, The Netherlands

e-mail: P.J.K.Kuppen@lumc.nl

G. Guertens · G. de Boeck · E. A. de Bruijn

LKI (Leuven Kanker Instituut),

Lab Proteomics and Pharmacology/LEO,

Herestraat 49, 30000 Leuven, Belgium

J. F. Nagelkerke

Department of Toxicology, Leiden Amsterdam Centre for Drug

Research, Leiden University, P.O. Box 9502,

2300 RA, Leiden, The Netherlands

G. Guertens

Department of Chemistry and Lab of Cancer Research and Clinical Oncology, Department of Medical Oncology, University of Antwerp (UA), Prinsstraat 13,

2000 Antwerp, Belgium
Results CC531 tumors did not show COX-2 expression. Tumor growth was significantly inhibited by celecoxib treatment in a dose dependent manner. Immune cell infiltration was decreased after celecoxib treatment, indicating that the immune system was not involved in preventing tumor growth. Tumor caspase-3 levels were only significantly increased if treatment was started before tumor inoculation. Celecoxib serum concentration starting at $0.84 \mu \mathrm{g} / \mathrm{ml}$ significantly inhibited the outgrowth of CC531 liver tumors. In contrast, in vitro concentrations of celecoxib of at least $12 \mu \mathrm{g} / \mathrm{ml}$ were needed to affect tumor cell viability.

Conclusion These results suggest that the inhibitory effects of celecoxib on tumor growth are not by direct cytotoxicity, but by creating an unfavorable environment for tumor growth.

Keywords Cyclooxygenase-2 - Prostaglandins . Immune response $\cdot$ CC531 rat colon tumor liver metastases model $\cdot$ Celecoxib

$\begin{array}{ll}\text { Abbreviations } \\ \text { COX-2 } & \text { Cyclooxygenase-2 } \\ \text { PGE }_{2} & \text { Prostaglandin } E_{2} \\ \text { AA } & \text { Arachidonic acid } \\ \text { TCR } & \text { T cell receptor } \\ \text { TH cells } & \text { T helper cells } \\ \text { NK cells } & \text { Natural Killer cells } \\ \text { ppm } & \text { Parts per million }\end{array}$

\section{Introduction}

In colon cancer, surgical resection potentially offers cure of the disease. Prognosis is mainly dependent on the occurrence of local or distant metastases, which occur in approximately 
$40 \%$ of the patients [1]. Epidemiological studies have indicated a considerable reduction in risk of occurrence of colorectal carcinomas that overexpress the cyclooxygenase2 (COX-2) enzyme in patients with reported long-term non steroidal inflammatory drugs (NSAID) use [2, 3]. In addition to the chemoprophylactic potential, chemotherapeutic effects of NSAIDs have been suggested and evaluated in in vitro, animal and clinical studies [4-6]. The mechanism by which NSAIDs reduce the risk of colorectal carcinogenesis is generally attributed to the inhibition of the arachidonic acid metabolism via the cyclooxygenase enzymes. COX is a critical step in the synthesis of prostaglandins (PG) that affects cell proliferation, tumor growth, apoptosis resistance and immune responsiveness $[7,8]$. Several isoforms of COX exist [9]. The isoform COX-2 is upregulated in many types of malignancies [10] and is responsible for prostaglandin $E_{2}$ $\left(\mathrm{PGE}_{2}\right)$ production by tumor cells. Several recent reports have suggested that COX-2 expression has an important role in haematogenous metastasis of colorectal carcinomas to the liver [11,12], however, the effects of COX-2 inhibition on the growth of established liver metastases remains unknown.

Tumor cells use various strategies to escape host immune surveillance, among others by impairing the effectivity of the host immune response [13]. Overproduction of PG and specifically $\mathrm{PGE}_{2}$ by tumor cells results in direct down regulation of effector cell cytotoxicity, but also creates an abnormal balance between the Thelper (TH)-1 and TH-2 response favoring the $\mathrm{TH}-2$, hereby functionally blunting the host anti-tumor cellular immune response [14, 15].

A recent animal study suggested that the inhibitory effect of COX-2 inhibitors on tumor growth is immunological and is dependent on the presence of B or T lymphocytes [16]. Given the immunomodulating nature of $\mathrm{PGE}_{2}$ production by tumor cells via COX-2 it has been suggested that COX-2 inhibition can result in an increased anti-tumor immune response by facilitating infiltration [15-17].

The aim of the present study was to investigate the effects of the COX-2 inhibitor celecoxib on the growth of established liver metastases by use of the CC531 rat tumor model $[18,19]$. In addition we evaluated the effects of celecoxib treatment on prostaglandin production, immune cell infiltration and apoptosis in the liver metastases.

\section{Materials and methods}

\section{Animals}

Twenty Male Wag/Rij rats weighing approximately $245 \mathrm{~g}$ were used (Charles River, Zeist, The Netherlands). All animals were housed in the animal facility of the Leiden University Medical Center. The animals had free access to food and water. The weight of the animals was followed throughout the experiment to monitor their general health state. Principles of laboratory animal care were followed and, according to Dutch law, the Animal Welfare Committee of the Leiden University Medical Center approved the study.

\section{Cell culture and liver metastasis model}

The colon adenocarcinoma cell line CC531 (1,2-dimethylhydrazine-induced) which is moderately differentiated and syngeneic to Wag/Rij rats [20] was used for tumor inoculation. Briefly, tumor cells were cultured in RPMI 1640 supplemented with $2 \mathrm{mM}$ L-glutamine (Gibco, Grand Island, NY, USA), $10 \%$ heat-inactivated fetal calf serum, $100 \mathrm{U} /$ $\mathrm{ml}$ penicillin and $0.1 \mathrm{mg} / \mathrm{ml}$ streptomycin sulphate (complete medium). Tumor cells were harvested with a solution of $0.25 \%(\mathrm{w} / \mathrm{v})$ EDTA and $0.25 \%(\mathrm{w} / \mathrm{v})$ trypsin in HBSS (Sigma, St. Louis, MO, USA), washed three times in $0.9 \%$ (w/v) $\mathrm{NaCl}$ solution buffered with $1.4 \mathrm{mM}$ phosphate (PBS) and adjusted to a suspension containing $1 \times 106$ viable (trypan blue exclusion test) tumor cells per ml PBS. For local liver tumor induction, $5 \times 104$ viable tumor cells (in $50 \mu$ suspension) per site were injected subcapsulary into the upper lobe of the liver at two sites.

\section{In vivo experimental design}

Rats were randomly assigned to one of the following five groups: (1) control group, (2) celecoxib 500 parts per million (ppm) starting at tumor inoculation, (3) celecoxib 1000 ppm starting at tumor inoculation, (4) celecoxib 1,500 ppm starting at tumor inoculation (5) celecoxib $1,500 \mathrm{ppm}$ starting 1 week before tumor inoculation (Fig. 1). Two tumors were inoculated as described above in the liver at day 0 . Tumors were allowed to grow for 21 days after which rats were sacrificed. Abdominal organs were evaluated for signs of toxicity. Liver tumors were separately enucleated from the surrounding liver parenchyma and measured. Blood samples were taken from all rats by aortal punction at time of sacrifice. Blood samples were allowed to coagulate and were centrifuged for $10 \mathrm{~min}$ at 13,000 rpm (Beckman

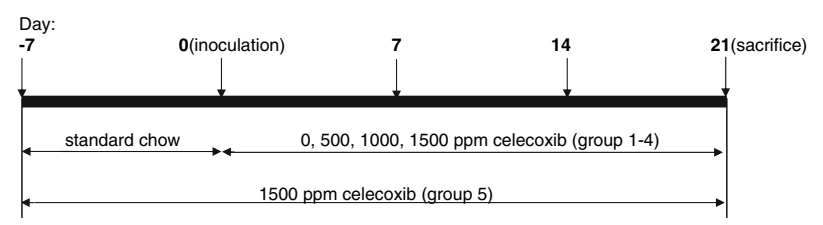

Fig. 1 Design of experiment with celecoxib treatment of CC531 tumors in a rat liver metastases model for colorectal cancer. Groups of four male Wag/Rij rats were fed 0, 500, 1,000, or 1,500 parts per million (ppm) celecoxib starting 7 days before (group 5) or directly after subcapsular tumor cell inoculation in the liver on day 0 (group 1-4). Rats were followed up for 21 days, after which they were sacrificed. After sacrifice, rat serum was collected and rat tumors were enucleated from the liver 
GS-6R centrifuge, Beckman Coulter, Fullerton, CA, USA); supernatants were collected and stored at $-20^{\circ} \mathrm{C}$ until analysis. The cross sectional tumor area was used for analyses. This was determined using the formula: $\mathrm{L} \times \mathrm{W} \times 0.25 \times \pi$ in which $L$ is maximum length and $W$ is maximum width of the tumor [21].

\section{Medication}

The COX-2 inhibitor celecoxib (SC-58635), obtained as a gift from Pfizer Pharmaceuticals, was incorporated into Altromin 1310 rat breeding diet by Altromin (Altromin Gesellschaft für Tierernährung $\mathrm{mbH}$, Lage, Germany) at various concentrations. Rats were fed this diet according to experimental design as indicated in Fig. 1.

Analysis of celecoxib concentrations in serum

A high-performance liquid chromatographic (HPLC) method was used and validated for the determination of celecoxib in serum. Ibuprofen was used as an internal standard. Blanc serum samples $(250 \mu \mathrm{l})$ were spiked with celecoxib (range $80 \mathrm{ng} / \mathrm{ml}-6,000 \mathrm{ng} / \mathrm{ml}$ ) and Ibuprofen $(2,000 \mathrm{ng} / \mathrm{ml})$ and used as calibrators and quality control samples. The limit of quantitation was $100 \mathrm{ng} / \mathrm{ml}$. Withinrun and between-run precisions were less than $10 \%$ and average accuracies were between 90 and $110 \%$. To $250 \mu \mathrm{l}$ of serum, $50 \mu \mathrm{l}$ internal standard work solution $(10 \mu \mathrm{g} / \mathrm{ml})$ [22] was added and the sample was mixed thoroughly. To precipitate the proteins, $1 \mathrm{ml}$ of acetonitrile was added and the sample was vortexed again. After centrifugation, the supernatant was transferred to a glass tube and evaporated till dry. The residue was resuspended in $1 \mathrm{ml}$ of the mobile phase [22] and filtered over a $0.45 \mu \mathrm{m}$ PVDF HPLC-filter (Acrodisc, Waters Corporation) for HPLC injection (40 $\mu \mathrm{l})$.

Separation was achieved on a Symmetry 300 C18 column $(25 \mathrm{~cm} \times 4.6 \mathrm{~mm}, 5 \mu \mathrm{m})$ (Waters, Milford, USA) connected to a Luna C18 guard column $(4 \times 3 \mathrm{~mm}, 5 \mu \mathrm{m})$ (Phenomenex, Torrance, USA). The mobile phase, which was filtered through a $0,20 \mu \mathrm{m}$ nylon filter before use, consisted of an acetonitrile-water-acetic acid-triethylamine (47:53:0,1:0,03) mixture and was pumped at a flow rate of $1 \mathrm{ml} / \mathrm{min}$. Celecoxib and Ibuprofen were detected by fluorescence detection. Emission and excitation wavelengths of Celecoxib and Ibuprofen were 280/340 and 253/300, respectively.

Analysis of $\mathrm{PGE}_{2}$ concentrations in liver metastases and serum

Tumor and serum levels of $\mathrm{PGE}_{2}$ were measured to analyse celecoxib activity in rats fed the control diets or diets supplemented with $500,1,000$ or $1,500 \mathrm{ppm}$. A competitive enzyme immunoassay (R\&D Systems Inc., Minneapolis MM 55413, USA) was used for the determination of $\mathrm{PGE}_{2}$ in serum and tumor tissue. The sensitivity of the $\mathrm{PGE}_{2}$ assay was typically higher than $13 \mathrm{pg} / \mathrm{ml}$. Each tissue sample (50-300 mg) was dried for surface moisture and accurately weighed. The sample was then homogenized in $1 \mathrm{ml}$ of distilled water. After centrifugation, the supernatant was treated the same way as serum.

\section{Measurement of Caspase-3 Activity in CC531 tumors}

The enzymatic activity of caspase-3 in treated and untreated CC531 tumors was measured as previously described [23]. Five $10-\mu \mathrm{M}$ crysostat sections of tumor or normal tissue were suspended in a lysis buffer consisting of $10 \mathrm{mM}$ HEPES, pH 7.0, $40 \mathrm{mM} \beta$-glycerophosphate, $50 \mathrm{mM} \mathrm{NaCl}, 2 \mathrm{mM} \mathrm{MgCl} \mathrm{2}$, and $5 \mathrm{mM}$ EGTA. After $10 \mathrm{~min}$ on ice, the cells were disrupted by four cycles of freezing and thawing and stored at $-80^{\circ} \mathrm{C}$. Protein concentration was determined using the method described by Bradford [24]. Caspase-3 activity was indicated in pmo$1 \mathrm{AMC} / \mathrm{min} / \mathrm{mg}$ protein.

Immunohistochemical staining of CC531 liver metastases

Cryostat sections (Cryocut 3000, Leica, Nuss-loch, Germany) $5 \mu \mathrm{m}$ thick were cut from the tumor tissue that was snap-frozen directly after resection, of the control group (group 1) and the group receiving celecoxib $1,500 \mathrm{ppm}$ (group 4). Sections were air-dried for at least $16 \mathrm{~h}$ at $60{ }^{\circ} \mathrm{C}$, then fixed in acetone for $10 \mathrm{~min}$ and washed twice in PBS. All dilutions of antibodies and conjugates were performed with PBS containing $1 \%(\mathrm{w} / \mathrm{v})$ bovine serum albumin (BSA, Boehringer, Mannheim, Germany). Immunohistochemistry for detection of tumor cell COX-2 expression was performed as described previously with a polyclonal anti-COX-2 antibody (ALX-210-711, Alexis, San Diego, CA, USA, 1:300 [25]). As negative controls sections were incubated with PBS instead the primary antibody. Immunohistochemical analysis of immune cell infiltration was performed as follows: The tissue sections were incubated for 30 min with a previously determined optimal concentration of protein-A-purified primary antibody. The monoclonal antibody (MAb) 3.2.3 IgG1 [26] (a gift from Dr. W.H. Chambers, University of Pittsburgh Cancer Institute, Pittsburgh, PA) was used for detection of CD161A (NKR$\mathrm{P} 1 \mathrm{~A}+$, Natural Killer cells) cells, the MAb R73 [27], antirat T-cell receptor (TCR) (a gift from Dr. Th. Hünig, University of Würzburg, Germany), was used for the detection of $\mathrm{T}$ cells. After incubation with the primary antibody, the sections were washed in PBS 3 times for $5 \mathrm{~min}$, followed by two 30-min incubations with horseradish-peroxidase (HRP)-conjugated rabbit anti-mouse Ig (dilution 1:100) and 
HRP-conjugated swine anti-rabbit Ig (dilution 1:50, both obtained from DAKO, Glostrup, Denmark) and subsequent washes in PBS. Visualization of immune complexes was performed by a 10-min incubation with a 3,3'-diaminobenzidine (DAB) substrate containing $1.8 \times 10 \mathrm{E}-3 \%$ (v/v) $\mathrm{H}_{2} \mathrm{O}_{2}$. A polyclonal rabbit anti-laminin antibody (Sigma-Aldrich) was used for the detection of laminin. After three wash steps with PBS, the sections were incubated for 30 min with HRP-conjugated swine anti-rabbit Ig (dilution 1:50, DAKO) for the detection of laminin. The immune complexes were visualized by a 12 -min incubation step in a buffered TRIS-HCl (pH 7.6) solution containing, per $100 \mathrm{ml}$, (1) $40 \mathrm{mg}$ 4-chloro-1-naphtol (Merck, Darmstadt, Germany) dissolved in $200 \mu \mathrm{l}$ dimethylformamide (Baker, Deventer, The Netherlands) and $300 \mu \mathrm{l}$ ethanol (Merck) and (2) $100 \mu \mathrm{l}$ of a $30 \%(\mathrm{v} / \mathrm{v}) \mathrm{H}_{2} \mathrm{O}_{2}$ solution (Merck). The sections were slightly counterstained using methyl green (Klinipath) and mounted using Kaiser's glycerine (Merck). Control sections (1 per tumor) were included in which both primary antibodies were omitted [20].

\section{Quantification of immunostaining}

After immunohistochemical staining slides were directly coded in order to blind the observer for tumor number or treatment group of the tumors. The number of tumor infiltrating R73+ and $323+$ cells in tumor epithelium were estimated using a scoring method described by Menon et al. [28]. In brief, an ocular grid, with a total surface area of $38 \mathrm{~mm} 2$, was used at a $200 \times$ magnification to count all leukocytes that were located intraepithelially in 25 different randomly chosen tumor fields of the tissue section. Laminin was used to distinguish between intraepithelially, that is, leukocytes in direct contact with tumor cells, and intrastromally located leukocytes (Fig. 3a-c). This tumor compartmentspecific analysis made it possible to calculate the number of leukocytes per tumor cell area (leukocytes/mm2 tumor epithelium). The mean leukocyte infiltration of 25 fields per tumor section was calculated and defined as the intraepithelial leukocyte infiltration. After evaluation, the slides were unblinded for treatment group for further analyses.

Effects of celecoxib on CC531 cell viability in vitro

The cell viability was assessed by the mitochondrial function, measured by 3-(4,5-dimethylthiazol-2-yl)-2,5-dipheniltetrazolium bromide (MTT) reduction activity as previously reported [29]. Briefly, cells were seeded in a 96well plate and incubated with increasing concentrations of celecoxib (Fig. 4). After $72 \mathrm{~h}$, the cells were incubated with $0.5 \mathrm{mg} / \mathrm{ml}$ MTT (Sigma-Aldrich) for $4 \mathrm{~h}$ at $37^{\circ} \mathrm{C}$. Subsequently, $100 \mu \mathrm{l}$ SDS (10\% (v/v) in $0.01 \mathrm{M} \mathrm{HCl})$ was added, after which the absorbance was read at $590 \mathrm{~nm}$, using a microplate reader (Bio-Rad Laboratories, Veenendaal, The Netherlands). Stock solutions of the pure compound celecoxib were made in dimethyl sulphide (DMSO). A final DMSO concentration of $0.1 \%$ in medium was used in all in vitro experiments including control experiments.

\section{Statistical analyses}

Statistical analysis between groups was performed using the Fisher exact test. Correlations between variables were evaluated using Spearmans' rank analysis, Mann-Whitney, Kruskal-Wallis, or student's $t$ test. Values with $P<0.05$ were considered statistically significant. The Statistical Package for Social Sciences (SPSS) version 12.0 was used for all statistical analyses.

\section{Results}

General condition of rats

The body weights of rats fed the control diet or the experimental diets containing various levels of celecoxib were comparable throughout the study. There was no difference in animal behavior between the treatment groups. Animals experienced a slight weight loss after laparotomy for inoculation of CC531 tumor cells in the liver, but no rats lost more than $5 \%$ body weight. The initial tumor induction was successful in all rats and no rats died before the end of the experiment. After sacrifice of the animals no gross intraabdominal changes were noted that would indicate toxicity.

Serum celecoxib levels

To establish if administration of celecoxib to rat diet resulted in adequate levels of celecoxib in rat serum, serum samples were collected after sacrifice. Increased dosage of celecoxib in the rat chow showed a corresponding increase in serum celecoxib levels (Fig. 2a). Rats in the control group who were fed regular chow had undetectable levels. Steady-state serum levels were as follows: celecoxib 500 ppm (group 2): $0.84 \pm 0.33 \mu \mathrm{g} / \mathrm{ml}$, celecoxib 1,000 ppm (group 3): $1.97 \pm$ $0.77 \mu \mathrm{g} / \mathrm{ml}$, celecoxib 1,500 ppm (group 4): $3.10 \pm 1.44 \mu \mathrm{g} /$ $\mathrm{ml}$, celecoxib $1,500 \mathrm{ppm}$ starting 1 week pre inoculation (group 5): $3.07 \pm 0.91 \mu \mathrm{g} / \mathrm{ml}$ (Fig. 2a, Table 1). Serum celecoxib levels in the present study were comparable with the $0.1-5.0 \mu \mathrm{M}$ concentrations in cancer patients treated with celecoxib $[5,30]$.

Effects of celecoxib treatment on liver metastasis growth

The effects of celecoxib administration on the tumor growth are summarised in Fig. 2b. Administration of celecoxib 

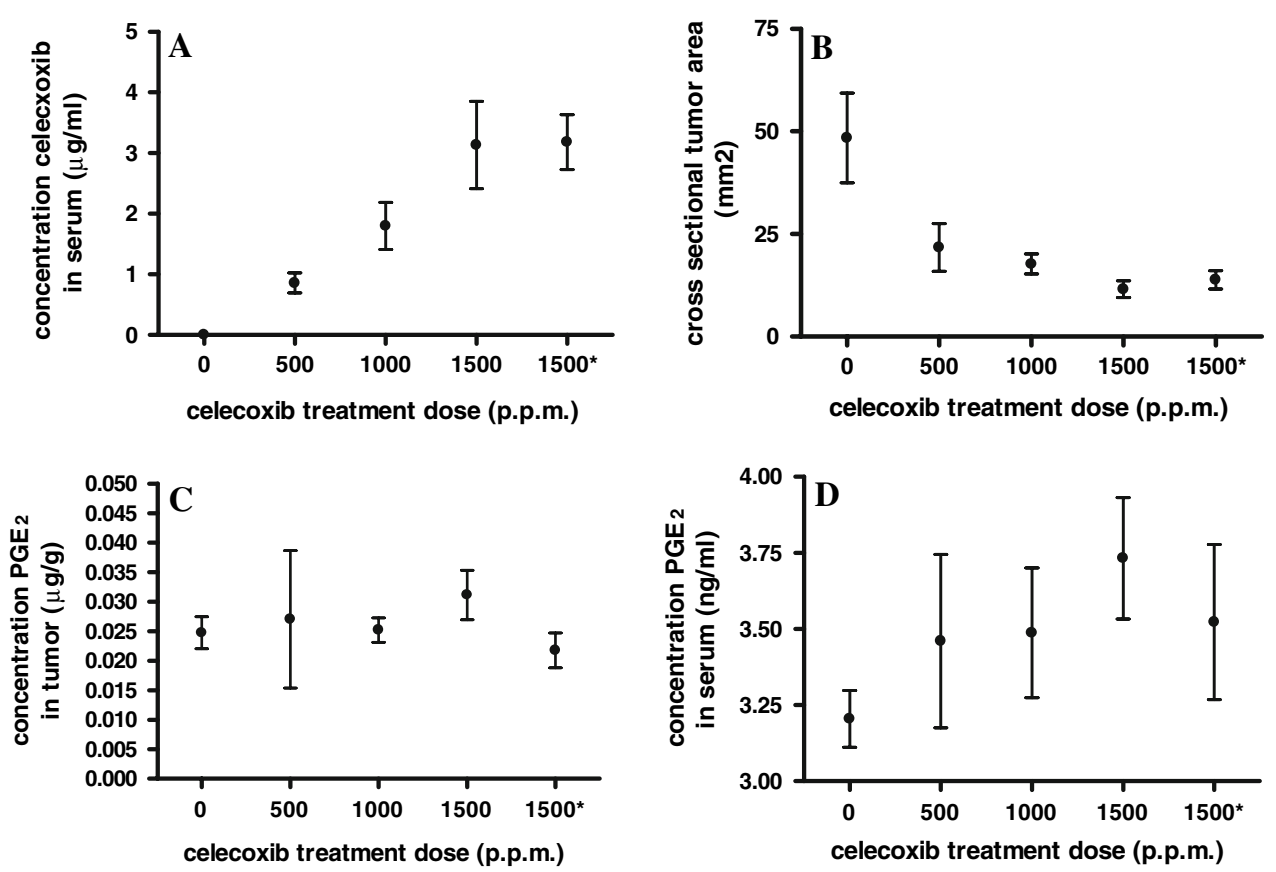

*celecoxib treatment started 7 days before tumor inoculation. In all other groups treatment started at inoculation.

Fig. 2 Effects of 21 days of celecoxib treatment on CC531 liver metastases and $\mathrm{PGE}_{2}$ serum and tumor level. All treatment groups consisted of 4 rats in each of which two tumors were inoculated subcapsularly in the liver. Rats received control diet, or a diet containing: celecoxib $500 \mathrm{ppm}$, celecoxib $1,000 \mathrm{ppm}$, celecoxib 1,500 ppm, starting at tumor inoculation, or celecoxib $1,500 \mathrm{ppm}$, starting 7 days before tumor inoculation. Blood and tumors were obtained from rats after

resulted in a significant dose dependent reduction of tumor size when compared to the rats that were fed control diet (group 1): Celecoxib $500 \mathrm{ppm}$ (group 2): $P=0.04$, celecoxib 1,000 ppm (group 3): $P=0.02$, celecoxib $1,500 \mathrm{ppm}$ (group 4): $P=0.006$, celecoxib $1,500 \mathrm{ppm}$ starting 1 week before inoculation (group 5): $P=0.007$ (Fig. 2b; Table 1) (Mann-Whitney). The administration of celecoxib 1 week before tumor cell inoculation did not significantly inhibit tumor growth compared to administration after inoculation (group 4) $(P=0.28)$

Effects of celecoxib treatment on tumor caspase-3 activity

To evaluate the effects of celecoxib on tumor cell apoptosis, caspase- 3 activity was determined in tumor samples of rats treated with high doses of celecoxib (celecoxib 1,500 ppm, group 4 and 5) as compared to the control group (group 1, see Fig. 1). Treatment with celecoxib $1,500 \mathrm{ppm}$ did not significantly increase tumor caspase-3 activity in the current study $(P=0.56)$. However, if celecoxib was given 1 week before tumor inoculation, celecoxib treatment resulted in increased caspase-3 activity $(P=0.03)$ (Table 1) (Mann-Whitney). sacrifice. Serum celecoxib levels and serum and tumor $\mathrm{PGE}_{2}$ levels were measured as described in the material and methods section. Values represent the mean and standard error. a Serum celecoxib concentrations. b Effects of celecoxib on tumor size (cross sectional tumor areas). $\mathbf{c} \mathrm{PGE}_{2}$ concentrations in the tumors of the rats. $\mathbf{d} \mathrm{PGE}_{2}$ concentrations in sera from the rats

Effects of celecoxib treatment on serum and tumor $\mathrm{PGE}_{2}$ levels

The effects of celecoxib on tumor and serum $\mathrm{PGE}_{2}$ levels can be seen in Fig. 2c, d and Table 1. No significant differences were found in tumor and serum $\mathrm{PGE}_{2}$ levels between the treatment groups ( $P=0.32$ and 0.51 respectively, Kruskal-Wallis).

\section{Tumor COX-2 expression}

COX-2 expression in CC531 tumors is shown in Fig. 3: All CC531 tumor cells were negative for COX-2 expression. Surrounding tumor stroma showed light brown immunostaining, this was not affected by celecoxib treatment. Infiltrating macrofages showed to be positive for $\mathrm{COX}-2$ and thus served as internal positive control for the test. All negative controls showed no immunoreactivity.

Effects of celecoxib treatment on infiltration of tumors by R73+ and 323+ cells

Previously, it was established that intraepithelial immune cells that are in direct contact with tumor target cells affect 


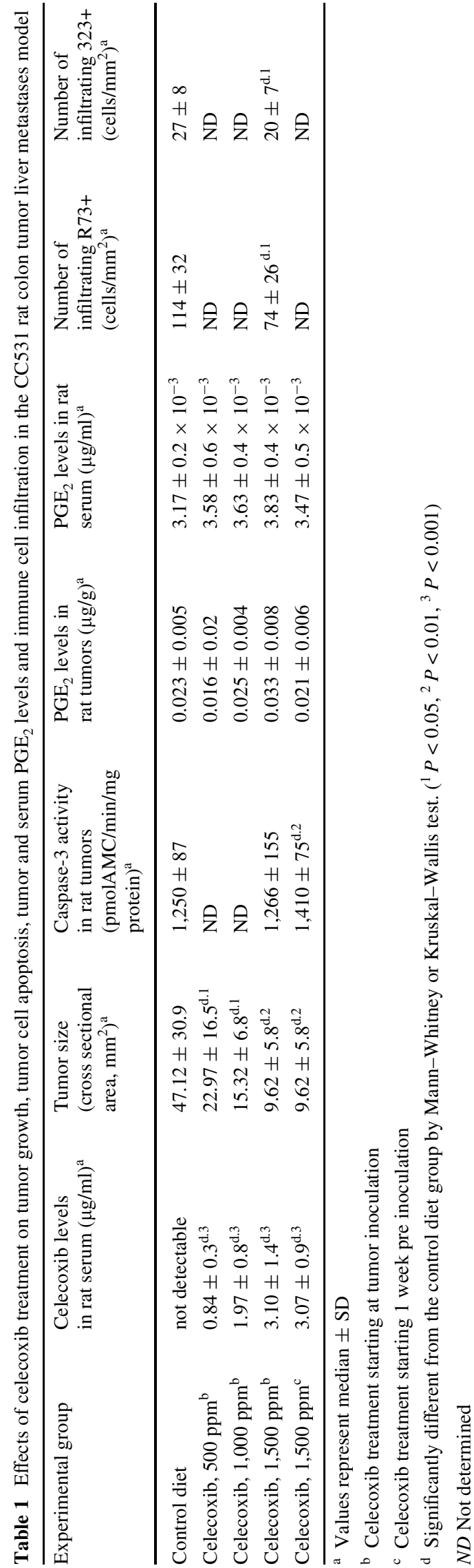

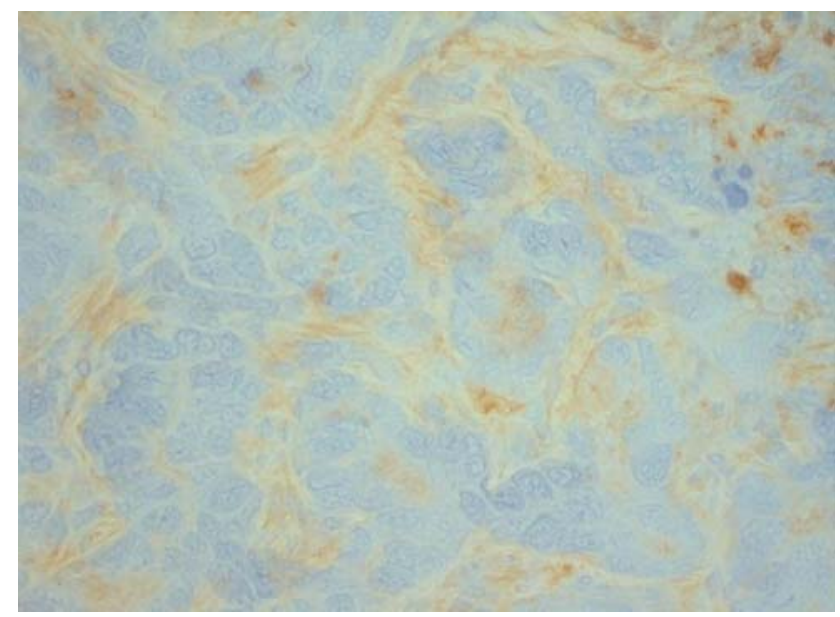

Fig. 3 Fresh frozen tumor sections from CC531 stained with polyclonal rabbit antibodies against COX-2 (1:300) at $\times 400$. COX-2 expression is not visible in tumor epithelium. Surrounding tumor stroma shows light brown imunoreactivity. Infiltrating macrophages show positive COX-2 expression

tumor growth [31]. Therefore, infiltration of intraepithelial immune cells in the tumor was evaluated. Figure $4 a-d$ shows the effects of celecoxib treatment on the intraepithelial infiltration of R73+ (TCR-positive cells, T cells) and 323+ (CD161A-positive cells, Natural Killer cells) cells. Intraepithelial infiltration of R73+ and 323+ cells was significantly diminished in the $1,500 \mathrm{ppm}$ celecoxib group (group 4) compared to the control group (group 1) $(P=0.01$ and 0.02 respectively) (Table 1$)$. Infiltration with $\mathrm{R} 73+$ cells was positively correlated with $323+$ cell infiltration $(P=0.03$, Spearmans' rank analysis).

Effects of Celecoxib administration on tumor cell viability in vitro

In the present study we observed that concentrations of $0.84 \mu \mathrm{g} / \mathrm{ml}$ were sufficient to reduce tumor growth. When CC531 cells were exposed to celecoxib concentrations equal to in vivo concentrations after $72 \mathrm{~h}$, no effect on cell viability was observed. In vitro, treatment with concentrations of at least $12 \mu \mathrm{g} / \mathrm{ml}$ or higher were needed to inhibit cell growth (mean \% cell viability $86.7 \pm 11.5, P=0.10$ ) and exposure to $24 \mu \mathrm{g} / \mathrm{ml}$ celecoxib resulted in a significant inhibition of cell viability as compared to the control group (mean \% cell viability $43.0 \pm 3.7, P<0.0001$, one sample $t$ test).

\section{Discussion}

The current study demonstrates that treatment of rats with levels of celecoxib equal to therapeutical levels in humans $[5,30]$, showed an inhibitory effect on the growth of liver metastases in a situation of low COX-2 and subsequent 
Fig. 4 A representative staining for $\mathrm{T}$ cell and $\mathrm{NK}$ cell infiltration of tumor sections from celecoxib-treated $(1,500 \mathrm{ppm})$ and -untreated rats 21 days after tumor inoculation. Sections were double-stained with laminin and R73 (anti-TCR, 1:100; a, c) or 323 (anti-CD161A, 1:50; b, d) antibodies respectively. R73+ and 323+ cells were stained brown, as revealed by immunohistochemistry (see material and methods). The matrix protein laminin was stained blue, blank spaces represent tumor nodules, delineated by a laminin-containing basal-membrane-like structure. The majority of R73+ and 323+ cells were localized in the tumor stroma, few positive cells were found in the tumor nodules. $(\times 200)$
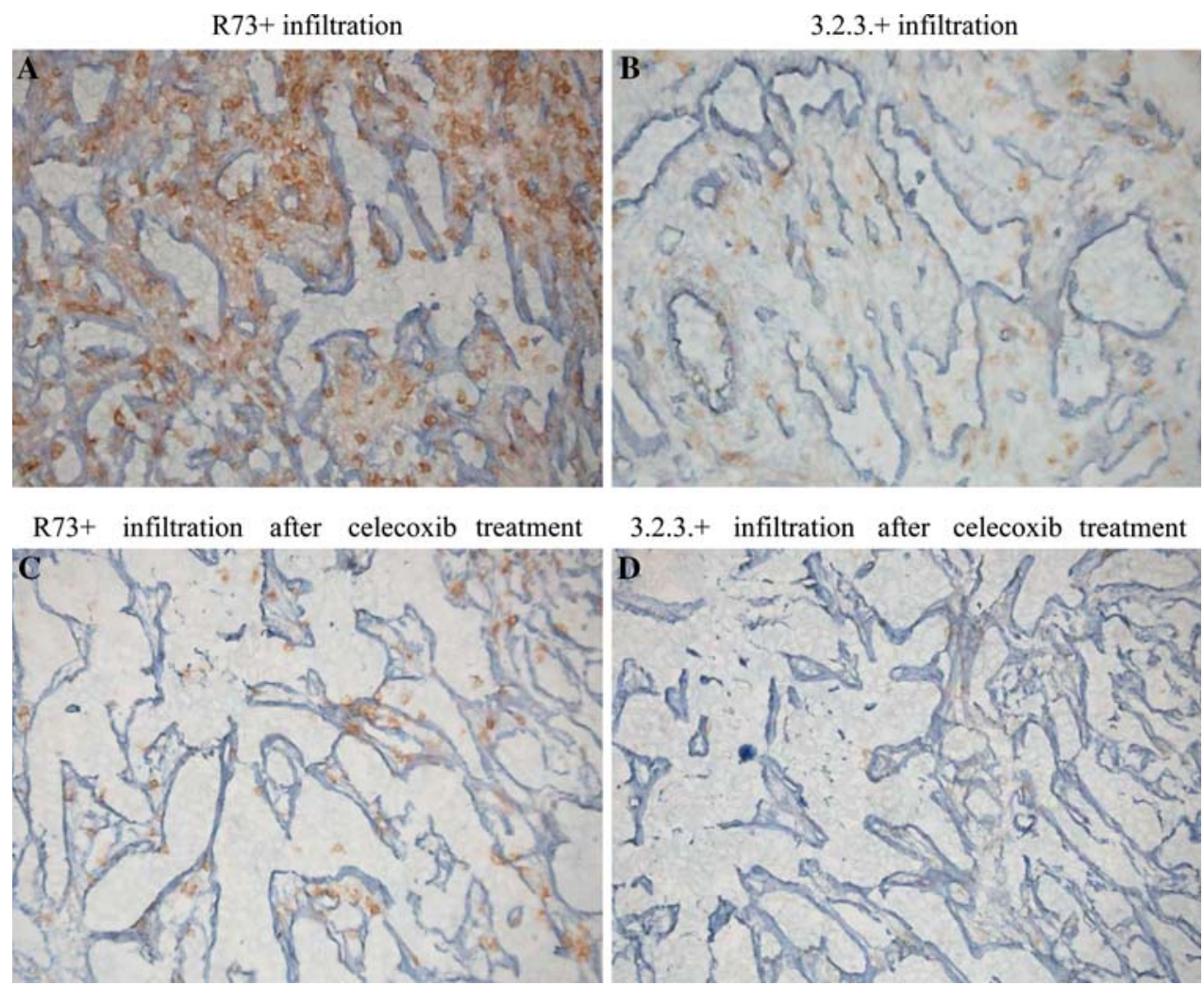

$\mathrm{PGE}_{2}$ activity. Recent RNA expression array data from a study by Germann et al. demonstrated that the CC531 cell line shows low COX-2 RNA expression [32]. The low COX-2 expression was confirmed in our study as tumor epithelium was negative for COX-2 immunostaining. In addition, $\mathrm{PGE}_{2}$ serum and tumor levels were not affected by celecoxib treatment. Furthermore, the level of $\mathrm{PGE}_{2}$, assumed to reflect COX-2 activity, was very low as compared to a similar study in a syngeneic mice model using MC-26 cell line, that showed a 2000-fold higher $\mathrm{PGE}_{2}$ production in untreated COX-2 positive tumors [33].

In our model, increasing levels of celecoxib were associated with a corresponding decrease in tumor size. Celecoxib is known to have direct cytotoxic effect on tumor cells as well as indirect effects, in which the immune system and angiogeneis is involved [8]. Treatment of CC531 cells in vitro for $36 \mathrm{~h}$ with concentrations of up to $12 \mu \mathrm{g} / \mathrm{ml}$ $(32 \mu \mathrm{M})$ did not have any significant effect on cell viability while in vivo already $0,84 \mu \mathrm{g} / \mathrm{ml}$ significantly inhibited tumor growth, suggesting no direct effect of celecoxib on tumor cell viability in vivo. In addition, treatment with celecoxib in vivo only resulted in an increase of tumor caspase-3 activity in the group that received celecoxib before tumor inoculation, whereas other groups showed no increase of caspase- 3 activity indicating that reduction of tumor growth can be achieved without induction of tumorcell apoptosis. These observations are supported by a study by Williams et al. [34] suggesting that celecoxib may create an unfavorable host environment for tumor growth. Several environmental interactions that determine tumor growth have been described to be affected by celecoxib treatment, including the immune system [35-38]. Infiltration of cytotoxic T-cells, NK cells and leukocytes is associated with improved prognosis in several malignancies and tumor cells utilise various strategies to escape the host immune surveillance [28, 31, 39]. In vitro production of $\mathrm{PGE}_{2}$ by COX-2 prevents activation of natural killer cells and T-cell mediated anti-tumor response, impairs the function of DC's and suppresses lymphocyte proliferation [15, 40-42]. The before mentioned studies suggest that these effects can be reversed by selective COX-2 inhibition. A recent study indicated that, in addition to enhancement of lymphocyte accumulation in tumors by COX-2 inhibition [15, 16], the anti-tumor effects of COX-2 inhibition are immunological and depend on the presence of lymphocytes in the tumor [16]. In the current study we quantified the immune cell infiltration: Surprisingly, we found a significant decrease in T-cell and NK-cell infiltration in tumors receiving celecoxib treatment, showing that the effect of celecoxib on tumor growth in our model can not be attributed to immune effector cells. A decrease in infiltration after treatment with NSAIDs or COX-2 inhibitors has been described in inflammatory processes as inflammatory bowel disease [43] and rheumatoid arthritis [44]. and indicates that the effects of COX-2 inhibition on tumor growth is not mediated through an increased anti-tumor immune response. 
Most studies evaluating the effects of COX-2 inhibition in tumor growth were performed with COX-2 overexpressing tumors. However it is estimated that $25-30 \%$ of human colorectal cancer does not express the COX-2 enzyme [45]. The results from the current study indicate that effects of COX-2 inhibitors on tumors with low COX-2 activity are still significant, but independent of tumor cell apoptosis and immune effector mechanisms. Mounting evidence indicates that the antitumor effects of NSAIDs and selective COX-2 inhibitors are not mediated predominantly through the inhibition of COX-2 activity and prostaglandin synthesis or even by induction of apoptosis [46-48]. A recent case-control study in colorectal cancer showed an interaction for NSAIDs use and IRS1 and VDR genotypes [49], suggesting that the protective effect of NSAID use involves a insulin-related growth pathway.

In conclusion, the current in vivo study has demonstrated the use of selective COX-2 inhibitor to limit the growth of colorectal liver metastases, in absence of COX-2 expression or prostaglandin production and independently of tumor cell apoptosis and immune effector mechanisms. This provides support for mechanisms other that COX-2 inhibition to be contributing to the protective effects of NSAIDs on colorectal cancer risk and suggest a beneficial effect in the prevention and treatment of colorectal cancer liver metastases by celecoxib use.

\begin{abstract}
Acknowledgments We thank Hans de Bont, Geeske Dekker-Ensink and Connie Janssen-van Rhijn for their excellent technical assistance. The study was designed by P.H., C.J.H.V and P.J.K.K.. All animal and in vitro experiments were performed by P.H., M.H.S. and M.M.K. Determination of $\mathrm{PGE}_{2}$ and celecoxib concentrations were performed by G.G., G.B. and E.A.B.. Immunohistochemical analysis of immune cell infiltration was performed by P.H. Caspase-3 levels were determined by F.J.N. J.M.C.J. performed statistical analyses. P.H. drafted the paper with help of P.J.K.K. and C.J.H.V.. Celecoxib was provided by Pfizer pharmaceuticals. All authors took part in the revision of the report and approved the final version.
\end{abstract}

Conflict of interest We declare no conflicts of interest.

Open Access This article is distributed under the terms of the Creative Commons Attribution Noncommercial License which permits any noncommercial use, distribution, and reproduction in any medium, provided the original author(s) and source are credited.

\section{References}

1. Labianca R, Beretta G, Gatta G, de Braud F, Wils J (2004) Colon cancer. Crit Rev Oncol Hematol 51:145-170

2. Thun MJ, Namboodiri MM, Heath CW Jr (1991) Aspirin use and reduced risk of fatal colon cancer. N Engl J Med 325:1593-1596

3. Chan AT, Ogino S, Fuchs CS (2007) Aspirin and the risk of colorectal cancer in relation to the expression of COX-2. N Engl J Med 356:2131-2142

4. Waskewich C, Blumenthal RD, Li H, Stein R, Goldenberg DM, Burton J (2002) Celecoxib exhibits the greatest potency amongst cyclooxygenase (COX) inhibitors for growth inhibition of
COX-2-negative hematopoietic and epithelial cell lines. Cancer Res 62:2029-2033

5. Steinbach G, Lynch PM, Phillips RK, Wallace MH, Hawk E, Gordon GB, Wakabayashi N, Saunders B, Shen Y, Fujimura T, Su LK, Levin B (2000) The effect of celecoxib, a cyclooxygenase-2 inhibitor, in familial adenomatous polyposis. N Engl J Med 342:19461952

6. Reddy BS, Hirose Y, Lubet R, Steele V, Kelloff G, Paulson S, Seibert K, Rao CV (2000) Chemoprevention of colon cancer by specific cyclooxygenase- 2 inhibitor, celecoxib, administered during different stages of carcinogenesis. Cancer Res 60:293-297

7. Sheng H, Shao J, Kirkland SC, Isakson P, Coffey RJ, Morrow J, Beauchamp RD, Dubois RN (1997) Inhibition of human colon cancer cell growth by selective inhibition of cyclooxygenase-2. J Clin Invest 99:2254-2259

8. Dubois RN, Abramson SB, Crofford L, Gupta RA, Simon LS, Van De Putte LB, Lipsky PE (1998) Cyclooxygenase in biology and disease. FASEB J 12:1063-1073

9. DuBois RN (1999) COX-2 in large bowel cancer: a one-sided story. Gut 45:636-637

10. Dannenberg AJ, Altorki NK, Boyle JO, Dang C, Howe LR, Weksler BB, Subbaramaiah K (2001) Cyclo-oxygenase 2: a pharmacological target for the prevention of cancer. Lancet Oncol 2:544-551

11. Chen WS, Wei SJ, Liu JM, Hsiao M, Kou-Lin J, Yang WK (2001) Tumor invasiveness and liver metastasis of colon cancer cells correlated with cyclooxygenase- $2(\mathrm{COX}-2)$ expression and inhibited by a COX-2-selective inhibitor, etodolac. Int J Cancer 91:894-899

12. Kakiuchi Y, Tsuji S, Tsujii M, Murata H, Kawai N, Yasumaru M, Kimura A, Komori M, Irie T, Miyoshi E, Sasaki Y, Hayashi N, Kawano S, Hori M (2002) Cyclooxygenase-2 activity altered the cell-surface carbohydrate antigens on colon cancer cells and enhanced liver metastasis. Cancer Res 62:1567-1572

13. Pardoll D (2003) Does the immune system see tumors as foreign or self? Annu Rev Immunol 21:807-839

14. Huang M, Stolina M, Sharma S, Mao JT, Zhu L, Miller PW, Wollman J, Herschman H, Dubinett SM (1998) Non-small cell lung cancer cyclooxygenase-2-dependent regulation of cytokine balance in lymphocytes and macrophages: up-regulation of interleukin 10 and down-regulation of interleukin 12 production. Cancer Res 58:1208-1216

15. Stolina M, Sharma S, Lin Y, Dohadwala M, Gardner B, Luo J, Zhu L, Kronenberg M, Miller PW, Portanova J, Lee JC, Dubinett SM (2000) Specific inhibition of cyclooxygenase 2 restores antitumor reactivity by altering the balance of IL-10 and IL-12 synthesis. J Immunol 164:361-370

16. DeLong P, Tanaka T, Kruklitis R, Henry AC, Kapoor V, Kaiser LR, Sterman DH, Albelda SM (2003) Use of cyclooxygenase-2 inhibition to enhance the efficacy of immunotherapy. Cancer Res 63:7845-7852

17. Rocca B, FitzGerald GA (2002) Cyclooxygenases and prostaglandins: shaping up the immune response. Int Immunopharmacol 2:603-630

18. Hagenaars M, Zwaveling S, Kuppen PJ, Ensink NG, Eggermont AM, Hokland ME, Basse PH, van de Velde CJ, Fleuren GJ, Nannmark U (1998) Characteristics of tumor infiltration by adoptively transferred and endogenous natural-killer cells in a syngeneic rat model: implications for the mechanism behind anti-tumor responses. Int J Cancer 78:783-789

19. van Duijnhoven FH, Tollenaar RA, Terpstra OT, Kuppen PJ (2005) Locoregional Therapies of Liver Metastases in a Rat CC531 Coloncarcinoma Model Results in Increased Resistance to Tumour Rechallenge. Clin Exp Metastasis 22:247-253

20. Hagenaars M, Ensink NG, Basse PH, Hokland M, Nannmark U, Eggermont AM, van de Velde CJ, Fleuren GJ, Kuppen PJ (2000) The microscopic anatomy of experimental rat CC531 colon 
tumour metastases: consequences for immunotherapy? Clin Exp Metastasis 18:189-196

21. Marinelli A, Dijkstra FR, van Dierendonck JH, Kuppen PJ, Cornelisse CJ, van de Velde CJ (1991) Effectiveness of isolated liver perfusion with mitomycin $\mathrm{C}$ in the treatment of liver tumours of rat colorectal cancer. Br J Cancer 64:74-78

22. Guirguis MS, Sattari S, Jamali F (2001) Pharmacokinetics of celecoxib in the presence and absence of interferon-induced acute inflammation in the rat: application of a novel HPLC assay. J Pharm Pharm Sci 4:1-6

23. Jonges LE, Nagelkerke JF, Ensink NG, van der Velde EA, Tollenaar RA, Fleuren GJ, van de Velde CJ, Morreau H, Kuppen PJ (2001) Caspase-3 activity as a prognostic factor in colorectal carcinoma. Lab Invest 81:681-688

24. Bradford MM (1976) A rapid and sensitive method for the quantitation of microgram quantities of protein utilizing the principle of protein-dye binding. Anal Biochem 72:248-254

25. Buskens CJ, Sivula A, van Rees BP, Haglund C, Offerhaus GJ, van Lanschot JJ, Ristimaki A (2003) Comparison of cyclooxygenase 2 expression in adenocarcinomas of the gastric cardia and distal oesophagus. Gut 52:1678-1683

26. Chambers WH, Vujanovic NL, DeLeo AB, Olszowy MW, Herberman RB, Hiserodt JC (1989) Monoclonal antibody to a triggering structure expressed on rat natural killer cells and adherent lymphokine-activated killer cells. J Exp Med 169:1373-1389

27. Hunig T, Wallny HJ, Hartley JK, Lawetzky A, Tiefenthaler G (1989) A monoclonal antibody to a constant determinant of the rat $\mathrm{T}$ cell antigen receptor that induces $\mathrm{T}$ cell activation. Differential reactivity with subsets of immature and mature $\mathrm{T}$ lymphocytes. J Exp Med 169:73-86

28. Menon AG, Fleuren GJ, Alphenaar EA, Jonges LE, Janssen-van Rhijn CM, Ensink NG, Putter H, Tollenaar RAEM, van de Velde CJH, Kuppen PJK (2003) A basal membrane-like structure surrounding tumor nodules may prevent intra-epithelial leukocyte infiltration in colorectal cancer. Cancer Immunol Immunother 52(2):121-126

29. Mosmann T (1983) Rapid colorimetric assay for cellular growth and survival: application to proliferation and cytotoxicity assays. J Immunol Methods 65:55-63

30. Raz A (2002) Is inhibition of cyclooxygenase required for the antitumorigenic effects of nonsteroidal, anti-inflammatory drugs (NSAIDs)? In vitro versus in vivo results and the relevance for the prevention and treatment of cancer. Biochem Pharmacol 63:343347

31. Menon AG, Janssen-van Rhijn CM, Morreau H, Putter H, Tollenaar RA, van de Velde CJ, Fleuren GJ, Kuppen PJ (2004) Immune system and prognosis in colorectal cancer: a detailed immunohistochemical analysis. Lab Invest 84:493-501

32. Germann A, Dihlmann S, Hergenhahn M, Doeberitz MK, Koesters R (2003) Expression profiling of CC531 colon carcinoma cells reveals similar regulation of beta-catenin target genes by both butyrate and aspirin. Int J Cancer 106:187-197

33. Yao M, Kargman S, Lam EC, Kelly CR, Zheng Y, Luk P, Kwong E, Evans JF, Wolfe MM (2003) Inhibition of cyclooxygenase- 2 by rofecoxib attenuates the growth and metastatic potential of colorectal carcinoma in mice. Cancer Res 63:586-592

34. Williams CS, Watson AJ, Sheng H, Helou R, Shao J, Dubois RN (2000) Celecoxib prevents tumor growth in vivo without toxicity to normal gut: lack of correlation between in vitro and in vivo models. Cancer Res 60:6045-6051

35. Masferrer JL, Leahy KM, Koki AT, Zweifel BS, Settle SL, Woerner BM, Edwards DA, Flickinger AG, Moore RJ, Seibert K (2000) Antiangiogenic and antitumor activities of cyclooxygenase-2 inhibitors. Cancer Res 60:1306-1311

36. Tsujii M, Kawano S, Tsuji S, Sawaoka H, Hori M, Dubois RN (1998) Cyclooxygenase regulates angiogenesis induced by colon cancer cells. Cell 93:705-716

37. Tuynman JB, Buskens CJ, Kemper K, ten Kate FJ, Offerhaus GJ, Richel DJ, van Lanschot JJ (2005) Neoadjuvant selective COX-2 inhibition down-regulates important oncogenic pathways in patients with esophageal adenocarcinoma. Ann Surg 242:840-9, discussion

38. Tuynman JB, Peppelenbosch MP, Richel DJ (2004) COX-2 inhibition as a tool to treat and prevent colorectal cancer. Crit Rev Oncol Hematol 52:81-101

39. Ohno Y, Ohno S, Suzuki N, Kamei T, Inagawa H, Soma G, Inoue M (2005) Role of cyclooxygenase-2 in immunomodulation and prognosis of endometrial carcinoma. Int J Cancer 114:696-701

40. Sano H, Kawahito Y, Wilder RL, Hashiramoto A, Mukai S, Asai K, Kimura S, Kato H, Kondo M, Hla T (1995) Expression of cyclooxygenase- 1 and -2 in human colorectal cancer. Cancer Res 55:3785-3789

41. Kojima M, Morisaki T, Uchiyama A, Doi F, Mibu R, Katano M, Tanaka M (2001) Association of enhanced cyclooxygenase-2 expression with possible local immunosuppression in human colorectal carcinomas. Ann Surg Oncol 8:458-465

42. Sharma S, Stolina M, Yang SC, Baratelli F, Lin JF, Atianzar K, Luo J, Zhu L, Lin Y, Huang M, Dohadwala M, Batra RK, Dubinett SM (2003) Tumor cyclooxygenase 2-dependent suppression of dendritic cell function. Clin Cancer Res 9:961-968

43. Geboes K, Dalle I (2002) Influence of treatment on morphological features of mucosal inflammation. Gut 50(Suppl 3):III37-III42

44. Kruithof E, De Rycke L, Roth J, Mielants H, Van den BF, De Keyser F, Veys EM, Baeten D (2005) Immunomodulatory effects of etanercept on peripheral joint synovitis in the spondylarthropathies. Arthritis Rheum 52:3898-3909

45. Yamauchi T, Watanabe M, Kubota T, Hasegawa H, Ishii Y, Endo T, Kabeshima Y, Yorozuya K, Yamamoto K, Mukai M, Kitajima M (2002) Cyclooxygenase-2 expression as a new marker for patients with colorectal cancer. Dis Colon Rectum 45:98-103

46. Hanif R, Pittas A, Feng Y, Koutsos MI, Qiao L, Staiano-Coico L, Shiff SI, Rigas B (1996) Effects of nonsteroidal anti-inflammatory drugs on proliferation and on induction of apoptosis in colon cancer cells by a prostaglandin- independent pathway. Biochem Pharmacol 52:237-245

47. Yamamoto Y, Gaynor RB (2001) Therapeutic potential of inhibition of the NF-kappaB pathway in the treatment of inflammation and cancer. J Clin Invest 107:135-142

48. Zhang X, Morham SG, Langenbach R, Young DA (1999) Malignant transformation and antineoplastic actions of nonsteroidal antiinflammatory drugs (NSAIDs) on cyclooxygenase-null embryo fibroblasts. J Exp Med 190:451-459

49. Slattery ML, Samowitz W, Hoffman M, Ma KN, Levin TR, Neuhausen S (2004) Aspirin, NSAIDs, and colorectal cancer: possible involvement in an insulin-related pathway. Cancer Epidemiol Biomarkers Prev 13:538-545 